\title{
International Conference on Advanced and Competitive Manufacturing Technologies
}

Svetlana Lukina (D lukina_sv@mail.ru )

Moskovskij gosudarstvennyj tehnologiceskij universitet STANKIN https://orcid.org/0000-0002-17510686

Elena Korshunova

Moscow State Technological University Stankin, 1 Vadkovsky line

\section{Research Article}

Keywords:

Posted Date: February 12th, 2021

DOI: https://doi.org/10.21203/rs.3.rs-189915/v1

License: (c) (i) This work is licensed under a Creative Commons Attribution 4.0 International License. Read Full License 


\section{Abstract}

The article considers methodology for assessing efficiency of digital transformation of industrial company production activity in a multi- techno-economic structure. The method allows forming, assessing and comparing a whole set of permitted alternative options of innovative solutions taking into account the set of technological repartitions of the business system of the industrial enterprise. It is shown that the imbalance of the multistructure of technological repartitions in industry is a serious barrier to its digital development. The massive introduction of cyberphysical systems into production, qualifying as the Industry 4.0 concept, is a global trend in the development of the technosphere. This concept involves the integration of modern information technology and communication networks with production equipment to organize, control and manage the entire chain of value creation processes in the product life cycle. The basis of the developed methodology is a complex of mathematical models for the formation of means of equipping production processes with digital technology; a total of partial criteria to assess the efficiency of the company production activity as a result of digital technology; searching for an optimal problem solution. A general system for the assessment include partial criteria of two classification groups: characterizing the manufacturing process and characterizing the production activity output. The process of digital transformation is presented in the form of the algorithm for the assessment of digital technology introduction efficiency within the already existing or being developed corporate information system. The automation of the developed method is conducted with software tools.

\section{Full Text}

Due to technical limitations, full-text HTML conversion of this manuscript could not be completed. However, the latest manuscript can be downloaded and accessed as a PDF.

\section{Figures}




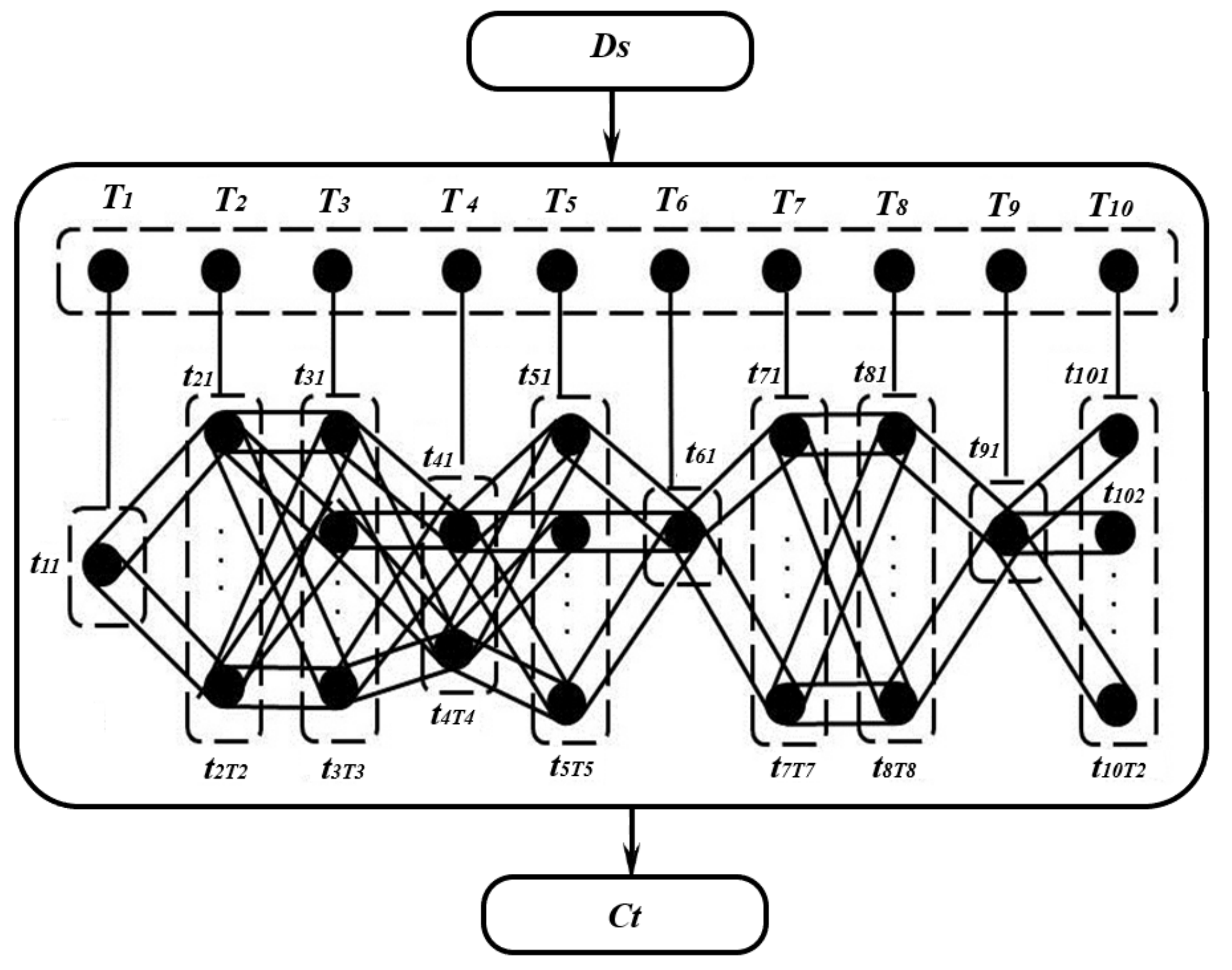

Figure 1

Graph-model 